\title{
Levels of Polycyclic Aromatic Hydrocarbons in Fried Tilapia Fish (O. niloticus) using GC-MS
}

\author{
Hafez NE ${ }^{1}$, Awad AM' ${ }^{1}$ Ibrahim SM², Mohamed $\mathrm{HR}^{2^{*}}$ \\ ${ }^{1}$ Department of Food Science and Technology, El-Fayoum University, Egypt \\ ${ }^{2}$ Fish Processing and Technology Laboratory, National Institute of Oceanography and Fisheries, Egypt
}

*Corresponding Author: Hassan Rabea Mohamed, Fish Processing and Technology Laboratory, Fisheries Division, National Institute of Oceanography and Fisheries, Egypt, E-mail: hassanaboali66@yahoo.com

Received: 11 October 2018; Accepted: 26 October 2018; Published: 14 November 2018

\begin{abstract}
This work was conducted to determine the safety levels of polycyclic aromatic hydrocarbons (PAHs) in deep oil fried tilapia fish obtained from two fish farms (A and B) located in Fayoum governorate, Egypt during June 2016. PAH compounds were determined by GC-MS. Results showed that the levels of total PAHs were 36.8 and 40.5 $\mu \mathrm{g} / \mathrm{kg}$ in both fried samples from farm A and B. Levels of B[a]P Equivalent of PAHs in fried Tilapia fish were 1.7099 and 0.0405 in farm A and B samples. Based on our results, it could be concluded that benzo[a]pyrene compound was not detectable in all fried samples which are considered as a safe product for human consumption.
\end{abstract}

Keywords: Fish; Frying; PAHs; GC-MS

\section{Introduction}

Polycyclic aromatic hydrocarbons (PAHs) are a group of environmental contaminants that originate from the pyrolysis or incomplete combustion of organic matter [1]. They are universal contaminants of our environment and of the human food chain [2]. Food Cooking and processing methods at high temperatures such as smoking, drying, roasting, baking or frying are recognized as a major source of food contamination by PAHs [3-5]. The nature of PAHs makes them present as trace contaminants in air, water and soil [6]. They are ubiquitous environmental contaminants that are formed during the incomplete combustion of carbonaceous materials [7]. Although air and drinking water may be responsible for some human exposure, the highest PAHs intake is typically associated with their occurrence in diet (food) [7]. The U.S. Environmental Protection Agency (EPA) selected 16 priority PAHs based on their occurrence and carcinogenicity. In recent years, studies have found that benzo[a]pyrene is not a suitable marker for PAHs occurrence in foods, since it is not a good indicator of the concentration of other 
carcinogenic PAHs. Thus, the use of the sum of eight genotoxic PAHs, benzo[a]pyrene equivalents (BaPeq), as well as the sum of four PAHs, including benzo[a]anthracene, chrysene, benzo[b]fluoranthene and benzo[a]pyrene was recommended [8-9]. The presence of PAHs in food is usually a consequence of the nature of these compounds in the environment at their formation during cooking processes or as a result of the manufacturing processes [10]. Electricplate grilling or frying would generate $\mathrm{PAHs}$ in cooked meat and fish, especially throughout the first cooking method which causes a highly rise in the formation of carcinogenic PAHs due to the direct contact of foods with the heat source leading to generate PAHs at a higher extent than the second one, as the result of incomplete combustion and pyrolysis of organic matter including proteins and fats [11]. Janoszka et al. [12], reported that the health hazard level of the PAHs daily ingested in the diet was found to be $3.7 \mu \mathrm{g}$ in Great Britain, $5.17 \mu \mathrm{g}$ in Germany, $1.2 \mu \mathrm{g}$ in New Zealand and $3 \mu \mathrm{g}$ in Italy. Also, FAO/WHO [13], reported that total PAHs level of $14 \mu \mathrm{g} / \mathrm{kg}$ in cooked and processed foods considered to be carcinogenic and mutagenic.

In [8], EFSA published an opinion on PAHs and concluded that $\mathrm{BaP}$ alone was not a suitable general marker for PAHs in food, but identified a group of 4 PAHs (PAH4) (the sum of benzo[a]pyrene, chrysene, benzo[a]anthracene, and benzo[b]fluoranthene) and a group of 8 PAHs (PAH8) (Benzo[a]anthracene, Chrysene, Dibenzo[a,h] anthracene, benzo[g,h,i]perylene, benzo[b]Fluoranthene, benzo[k] fluoranthene, benzo[a]Pyrene, Indeno[1,2,3c,d]Pyrene) as better indicators based on data related to occurrence and toxicity. Measuring PAH8 offered little additional benefit compared with PAH4. Based on the EFSA opinion, the European Commission extended the scope of the regulation to include other types of food and to add limits for PAH4 [14]. As oil breaks down, it produces compounds that cause off-flavours and darkening, some of which may be toxic at high concentrations. Some volatile compounds formed during deep-fat frying are known to be toxic (e.g. 1,4-dioxane, benzene, toluene and hexylbenzene) or potentially carcinogenic, such as carbonyl compounds or monoepoxides and some aldehydes produced from linoleic acid (e.g. 4-hydroxy-2-transnonenal which has been proven to be cytotoxic) [15]. Therefore, this study was designed to determine the safety level of PAHs in deep-oil fried tilapia fish samples that were obtained during June 2016 from two fish farms localized at El-Fayoum governorate, Egypt.

\section{Materials and Methods}

\subsection{Fish samples}

Tilapia fish (O. niloticus) samples were obtained after directly catch from two fish farms (A and B). The main resources of irrigation water were agricultural discharge for A (Al-Batts drain) and B (El Wadi drain) during June 2016 at Fayoum Governorate. They were transported within two hours using ice box to Fish Processing and Technology Lab, Shakshouk Station for Water Resource, National Institute of Oceanography and Fisheries (NIOF), Egypt. Average weight was $303 \pm 31.5 \mathrm{gm}$ and length $25.9 \pm 0.22 \mathrm{~cm}$ for raw samples from Farm A also; average weight and length of raw mullet samples from Farm B are $327 \pm 93.8 \mathrm{gm}$ and $26 \pm 2.8 \mathrm{~cm}$, respectively. 


\subsection{Frying process}

Frying process was carried out as shown in Figure 1. The prepared fish was rubbed with flour left for 3-4 min and fried in pre-heated deep fried oil at $170-180^{\circ} \mathrm{C}$ for $10-15$ min using Electrical Fryer pan (Moulinex brand). Fried fish samples were removed when a golden brown color was appeared on their surfaces. They were placed in the frying basket to drain out the excess amounts of cooking oil then cooled and kept for analysis.

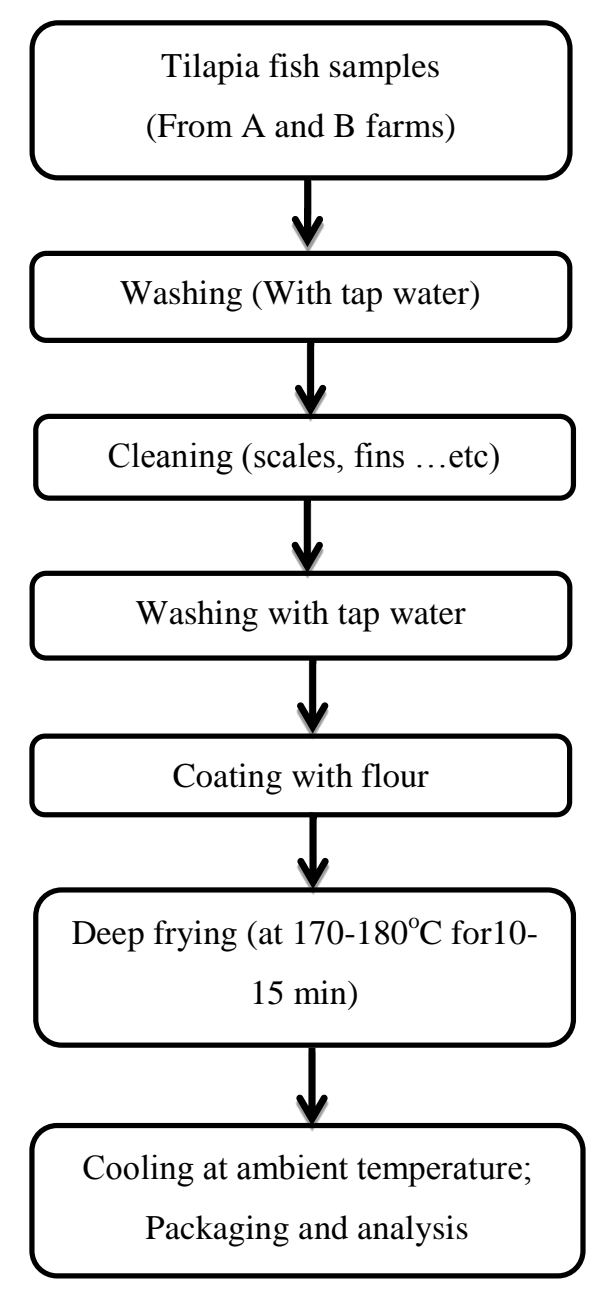

Figure 1: Flowchart of Tilapia fish frying.

\subsection{Analytical methods}

The edible of fried tilapia fish products was manually separated, homogenized, packed in polyethylene bags and then stored in a freezer at $-20^{\circ} \mathrm{C}$ till analysis.

2.3.1 PAHs determination: PAHs were determined at Central Laboratory of Residue Analysis of Pesticides and Heavy Metals in Food (QCAP), Agricultural Research Centre. Cairo, Egypt as described by Forsberg et al. [16], Smoker et al. [17] and Khorshid et al. [18]. Helium gas was used as the carrier gas; the column was maintained at a constant flow rate of $1.3 \mathrm{ml} / \mathrm{min}$. The back injector line was maintained at $260^{\circ} \mathrm{C}$. Injection volumes were $1.0 \mu \mathrm{l}$ in 
the split less mode. The column temperature was initially held at $90^{\circ} \mathrm{C}$ for $2 \mathrm{~min}$, ramping to $180^{\circ} \mathrm{C}$ at a rate of $15^{\circ} \mathrm{C} / \mathrm{min}$, held at $180^{\circ} \mathrm{C}$ for $15 \mathrm{~min}$, ramping to $250^{\circ} \mathrm{C}$ at a rate of $10^{\circ} \mathrm{C} / \mathrm{min}$, held for $2 \mathrm{~min}$, ramping to $290^{\circ} \mathrm{C}$ at a rate of $10^{\circ} \mathrm{C} / \mathrm{min}$, and held for $10 \mathrm{~min}$.

\section{B $\{$ a $\}$ P equivalent:}

The $\mathrm{B}\{\mathrm{a}\}$ Peq was calculated as the $\Sigma \mathrm{B}\{\mathrm{a}\}$ Peqi value for individual PAHs. The $\mathrm{B}\{\mathrm{a}\}$ Peqi calculated as the following equation:

$\mathrm{BaPeq}=\Sigma(\mathrm{BaPeqi})=\Sigma(\mathrm{CPAHi} \times \mathrm{TEFPAHi})$

CPAHi: Concentration of each PAH in the sample; TEFPAHi: Toxic equivalency factor for each individual PAH.

2.3.2 Statistical analysis: The results obtained were analyzed statistically using the least significant difference test $(\mathrm{LSD})$ at $(\mathrm{P} \leq 0.05)$ and were expressed as Mean, SD using SPSS 16 for windows.

\section{Results and Discussion}

\subsection{Polycyclic aromatic hydrocarbons (PAHs)}

Polycyclic aromatic hydrocarbons compounds (PAHs) were determined in edible part of fried tilapia fish samples including; naphthalene (NA), acenaphthylene (ACL), acenaphthene (ACE), fluorine (FLU), phenanthrene (PHE), anthracene (ANT), fluoranthene (FLA), pyrene (PYR), benzo[a]anthracene (BaA), chrysene (CHR), benzo[b]fluoranthene $(\mathrm{BbF})$, bonzo[k]fluoranthene $(\mathrm{BkF})$, benzo[a]pyrene $(\mathrm{BaP})$, dibenzo[a,h]anthracene $(\mathrm{DahA})$, benzo[g,h,i]pyrene (BghiP) and indeno[1,2,3-cd]pyrene (IcdP). The results obtained are given in Table (1). Benzo[a]anthracene, Phenanthrene and Chrysene were detected in farm A samples with amounts 16.9, $19.9 \mu \mathrm{g} / \mathrm{kg}$ and $<\mathrm{LOQ}(<2 \mu \mathrm{g} / \mathrm{kg})$ respectively. The total amounts of PAHs were $36.8 \mu \mathrm{g} / \mathrm{kg}$ in farm A sample. While only Naphthalene was detected in farm B sample with amount $40.5 \mu \mathrm{g} / \mathrm{kg}$. Our results agreed with Phillips [19] and Anderson et al. [11], who reported that electric-plate grilling or frying would generate PAHs in cooked meat and fish, and El-Badry et al. [20], who found that the amounts of PAHs increased after frying of tilapia fish.

\subsection{B $\{$ a\}P Equivalent of PAHs and toxic equivalent factors (TEFs)}

Benzo[a]Pyrene $(\mathrm{BaP})$ has been well characterized as the most potent carcinogenic PAH after ibenz[a,h]anthracene. Therefore, the total PAH concentration is expressed as Benzo[a]Pyrene Equivalents (BaPeq) to illustrate the toxic potency [21]. The BaPeqi was calculated as the sum of BaPeqi value for individual PAHs. The BaPeqi value was calculated for each PAH from its concentration in the sample (CPAHi) multiplied by its toxic equivalency factor (TEFPAHi) [22].

BaPeqi $=\sum($ BaPeqi $)=\sum($ CPAHi $\times$ TEFPAHi $)$ 
Table (2) shows the toxic equivalent factors (TEFs) and B[a]P Equivalent of PAHs in fried tilapia fish samples obtained from A and B farms. The B[a]P Equivalent of Phenanthrene and Benzo(a)anthracene were 0.0199 and 1.69 respectively for farm $\mathrm{A}$ and the sum of $\mathrm{B}[\mathrm{a}] \mathrm{P}$ Equivalents $\sum$ (BaPeqi ) 1.7099. On other side the $\mathrm{B}[\mathrm{a}] \mathrm{P}$ Equivalent of Naphthalene was 0.0405 for farm B and the sum of B[a]P Equivalents $\sum$ (BaPeqi) 0.0405 .

\begin{tabular}{|c|c|c|c|c|c|}
\hline \multirow{2}{*}{ Compound } & \multirow{2}{*}{ Abbrev. } & \multirow{2}{*}{ Mw } & \multirow{2}{*}{ Rings } & \multicolumn{2}{|c|}{ Concentration $(\mu \mathrm{g} / \mathrm{kg})$} \\
\hline & & & & Farm (A) & Farm (B) \\
\hline Chrysene & $\mathrm{CHR}$ & 228 & 4 & $<$ LOQ & ND \\
\hline Anthracene & ANT & 178 & 3 & ND & ND \\
\hline Acenaphthene & ACE & 154 & 3 & ND & ND \\
\hline Benzo[b]fluoranthene & $\mathrm{BbF}$ & 252 & 5 & ND & ND \\
\hline Benzo[k]fluoranthene & $\mathrm{BkF}$ & 252 & 5 & ND & ND \\
\hline Dibenzo[a,h]anthracene & DahA & 278 & 5 & ND & ND \\
\hline Fluorene & FLU & 166 & 3 & ND & ND \\
\hline Naphthalene & NA & 128 & 2 & ND & 40.5 \\
\hline Benzo[a]pyrene & $\mathrm{BaP}$ & 252 & 5 & ND & ND \\
\hline Benzo[g,h,i]perylene & BghiP & 276 & 6 & ND & ND \\
\hline Indeno $[1,2,3$, cd $]$ pyrene & IcdP & 276 & 6 & ND & ND \\
\hline Acenaphthylene & ACY & 152 & 3 & ND & ND \\
\hline Fluoranthene & FLA & 202 & 4 & ND & ND \\
\hline Pyrene & PYR & 202 & 4 & ND & ND \\
\hline Benzo[a]anthracene & $\mathrm{BaA}$ & 228 & 4 & 16.9 & ND \\
\hline Phenanthrene & PHE & 178 & 3 & 19.9 & ND \\
\hline \multicolumn{4}{|l|}{$\Sigma$ 16PAHs } & 36.8 & 40.5 \\
\hline
\end{tabular}

Farm (A): Al-Batts drain; Farm (B): El-Wadi drain; Mw: Molecular weight; LOQ: $2 \mu \mathrm{g} / \mathrm{kg}$

Table 1: The concentrations of PAHs in fried tilapia samples. 


\begin{tabular}{|c|c|c|c|c|c|}
\hline \multirow[b]{2}{*}{ Compound } & \multirow[b]{2}{*}{ TEF } & \multicolumn{2}{|c|}{ Farm (A) } & \multicolumn{2}{|c|}{ Farm (B) } \\
\hline & & $\begin{array}{l}\text { Conc. } \\
(\mu \mathrm{g} / \mathrm{kg})\end{array}$ & $\mathbf{B a P}_{\text {eqi }}$ & $\begin{array}{l}\text { Conc. } \\
(\mu \mathrm{g} / \mathrm{kg})\end{array}$ & $\mathbf{B a P}_{\text {eqi }}$ \\
\hline Naphthalene & 0.001 & ND & ND & 40.5 & 0.0405 \\
\hline Acenaphthylene & 0.001 & ND & ND & ND & ND \\
\hline Acenaphthene & 0.001 & ND & ND & ND & ND \\
\hline Fluorene & 0.001 & ND & ND & ND & ND \\
\hline Phenanthrene & 0.001 & 19.9 & 0.0199 & ND & ND \\
\hline Anthracene & 0.01 & ND & ND & ND & ND \\
\hline Fluoranthene & 0.001 & ND & ND & ND & ND \\
\hline Pyrene & 0.001 & ND & ND & ND & ND \\
\hline Benzo[a]anthracene & 0.1 & 16.9 & 1.69 & ND & ND \\
\hline Chrysene & 0.01 & $\mid<\mathrm{LOQ}$ & ND & ND & ND \\
\hline Benzo[b]fluoranthene & 0.1 & ND & ND & ND & ND \\
\hline Benzo[k]fluoranthene & 0.1 & ND & ND & ND & ND \\
\hline Benzo[a]pyrene & 1 & ND & ND & ND & ND \\
\hline Indeno[1,2,3,c]pyrene & 0.1 & ND & ND & ND & ND \\
\hline Dibenzo[a,h]anthracene & 1 & ND & ND & ND & ND \\
\hline Benzo[g,h,i]perylene & 0.01 & ND & ND & ND & ND \\
\hline$\sum\left(\mathbf{B a P}_{\text {eqi }}\right)$ & & & 1.7099 & & 0.0405 \\
\hline
\end{tabular}

TEF: Toxic equivalent factor; $\mathrm{BaP}_{\text {eqi }}$ [a]: P equivalent; LOQ: $2 \mu \mathrm{g} / \mathrm{kg}$; Farm (A): Al-Batts drain; Farm (B): El-Wadi drain

Table 2: Toxic Equivalent factors (TEFs) and B [a] P Equivalent of PAHs in fried Tilapia fish.

\section{Conclusion}

In conclusion, the safety of fried fish has been controlled by measuring benzo[a]pyrene level, which is one of the most carcinogenic PAHs. European Commission has limited the maximum acceptable concentrations of benzo[a]pyrene at $2 \mathrm{ppb}$ for smoked fish and smoked fishery products, excluding bivalve molluscs. In addition, the levels of B[a]P Equivalent of PAHs in fried Tilapia fish were 1.7099 and 0.0405 in farm A and B samples. Based on 
our results, it could be concluded that Benzo[a]pyrene compound was not detectable in all fried samples which are considered as a safe product for human consumption.

\section{References}

1. Costes JM, Druelle V. Polycyclic aromatic hydrocarbons in the environment: the rehabilitation of former industrial sites. Rev of the French Institute of Petroleum 52 (1997): 425-445.

2. Lacoste F, Raoux R, Dubois D, et al. Problematic of polycyclic aromatic hydrocarbons in crops. Oleagineux, Corps gras, Lipides 10 (2003): 287-295.

3. CCFAC. Codex Committee on Food Additives and Contaminants. Discussion paper on polycyclic aromatic hydrocarbons contamination. $37^{\text {th }}$ Session, The Hague, the Netherlands (2005).

4. Moret S, Purcaro G, Conte LS. Polycyclic aromatic hydrocarbons in smoked fish by gas chromatography mass spectrometry with positive-ion chemical ionization. J Food Comp Anal 18 (2005): 857-869.

5. Yurchenko S, Molder U. The determination of polycyclic aromatic hydrocarbons in smoked fish by gas chromatography mass spectrometry with positive-ion chemical ionization. J of Food Composition and Analysis 18 (2005): 857-869.

6. Pigini D, Cialdella AM, Feranda $\mathrm{P}$, et al. Comparison between external and internal standard calibration in the validation of an analytical method for 1-hydroxy Pyrene in human urine by high-performance liquid chromatography/ tandem mass spectrometry. Wiley Inter Sci 20 (2006): 1013-1018.

7. Suchanova M, Haj LJ, Tomaniova M, et al. Polycyclic aromatic hydrocarbons in smoked cheese. J Sci food Agric 88 (2008): 1307-1317.

8. EFSA. European Food Safety Authority. Scientific Committee on Food. Opinion on the risks to human health of polycyclic aromatic hydrocarbons in food. Italy (2002).

9. Alomirah HF, Al-Zenki SF, Sawaya WN, et al. Assessment of the food control system. In Purcaro G, Moret S, Conte LS. Overview on polycyclic aromatic hydrocarbons: Occurrence, legislation and innovative determination in foods. Talanta 105 (2013): 292-305. State of Kuwait. Food Control 21 (2010): 496-504.

10. FSA. Food Standards Agency. Olive-pomace oil: your questions answered (2001).

11. Anderson KE, Sinha R, Kulldorff M, et al. Meat intake and cooking techniques: Associations with pancreatic cancer. Mutat Res 30 (2002): 506-507: 225-231.

12. Janoszka B, Warzecha L, Błaszczyk U, et al. Organic compounds formed in thermally treated high-protein food. Part I: polycyclic aromatic hydrocarbons. Acta Chromatographica 14 (2004): 115-128.

13. FAO/WHO. Food and Agriculture Organization of the United Nations/World Health Organization. Joint FAO/WHO Expert Committee on Food Additives (JECFA). Sixty-fourth meeting, Rome (2005).

14. EC. European Commission. European Commission Regulation (EC) No 835/2011 of 19 August 2011 amending Regulation (EC) No 1881/2006 as regards maximum levels for polycyclic aromatic hydrocarbons in foodstuffs. Official J of the European Union, 215 (2011): 4-8.

15. Bordin K, Kunitake MT, Aracava KK, et al. Changes in food caused by deep fat frying. A review. Arch Latin Amer Nutr 63 (2013): 5-13. 
16. Forsberg ND, Wilson GR, Anderson KA. Determination of parent and substituted polycyclic aromatic hydrocarbons in high-fat salmon using a modified QuEChERS extraction, dispersive SPE and GC-MS. J Agric Food Chem 10 (2011): 8108-8116.

17. Smoker M, Tran K, Smith RE. Determination of polycyclic aromatic hydrocarbons (pahs) in shrimp. J Agric Food Chem 58 (2010): 12101-12104.

18. Khorshid M, Souaya ER, Hamzawy AH, et al. QuEChERS method followed by solid phase extraction method for gas chromatographic mass spectrometric determination of polycyclic aromatic hydrocarbons in fish. Int J Analytical Chem 7 (2015): 205-217.

19. Phillips DH. Polycyclic aromatic hydrocarbons in the diet, Mutat. Res./Genet. Toxicol Environ Mutagenesis 443 (1999): 139-147.

20. El-Badry N, Abul-Fadl M, Sharaf AM, et al. PAHs formation in cooked tilapia fish and beef fingers as affected by cooking method and some food additives. J of agric Sci Mansoura univ 31 (2006): 5179-5192.

21. Perugini M, Visciano P, Giammarino A, et al. Polycyclic aromatic hydrocarbons in marine organisms from the Adriatic Sea, Italy. Chemosphere 66 (2007): 1904-1910.

22. Nisbet ICT, LaGoy PK. Toxic equivalency factors (TEFs) for polycyclic aromatic hydrocarbons (PAHs). Regulatory Toxicology and Pharmacology 16 (1992): 290-300.

23. Scientific Committee on Foods of EC, SCF. Opinion of the Scientific Committee on Food in the Risk to Human Health of PAHs in Food. Scientific Committee on Foods of EC, SCF, Brussels (2002).

Citation: Hafez NE, Awad AM, Ibrahim SM, Mohamed HR. Levels of Polycyclic Aromatic Hydrocarbons in Fried Tilapia Fish (O. niloticus) using GC-MS. Journal of Food Science and Nutrition Research 1 (2018): 010-017.

(C) 9 BY ${ }_{\text {Creative Commons Attribution (CC-BY) license 4.0 }}^{\text {This article is an open access article distributed under the terms and conditions of the }}$

